\title{
Tuna Massage Training as An Effort to Improve the Nutritional Status of Toddlers
}

\author{
Sumarni Sumarni ${ }^{a}$, and Fitria Prabandari \\ Program Studi S1 Kebidanan, Universitas Muhammadiyah Gombong, Gombong, Indonesia \\ a)Corresponding Author: sumarni2880@gmail.com
}

\begin{abstract}
Difficulty eating in children cause malnutrition, dehydration, underweight, electrolyte imbalance, impaired cognitive development, anxiety disorders, and in more severe cases can be a life-threatening condition. Tuina massage is a massage technique that can overcome eating difficulties in toddlers. The purpose of this activity is to increase the knowledge and skills of health cadres about nutritional health and Tuina massage. The service was carried out in Pasir Lor village, Karanglewas district, which was attended by 23 cadres. Data collection techniques were carried out using questionnaires about toddler nutrition and observation sheets to assess Tuina's massage skills. The results of the activity showed that the knowledge of cadres before training was mostly in the sufficient category, while the knowledge of cadres after attending the training showed that the level of knowledge of cadres was mostly in the good category. Most of the health cadres have good skills in doing Tuina massage. The training activities were effective and able to increase the knowledge and skills of cadres about toddler nutrition and developmental problems and Tuina massage.
\end{abstract}

Keywords: Knowledge, Skills, Tuina Massage

\section{INTRODUCTION}

Toddlers are a nutritionally vulnerable age group. Inadequate nutritional intake in the first five years can result in irreversible growth and development disorders, both physical, mental, and brain. (Wirandoko, 2007) Ages 1-5 years are the nutritionally vulnerable age group. Inadequate nutritional intake in the first five years can result in irreversible growth and development disorders, both physical, mental, and brain. Difficulty eating is a problem in providing food and meeting nutritional needs that are generally found in children and become a health problem throughout the world (Chung, 2006).

Difficulty eating is a problem in providing food and meeting nutritional needs that are generally found in children and become a health problem throughout the world (Chung, 2006). Most feeding difficulties in infants are related to growth disorders while feeding difficulties in children are accompanied by developmental disorders. Difficulty eating in children who are not treated immediately can cause malnutrition, dehydration, underweight, electrolyte imbalance, impaired cognitive development, anxiety disorders, and in more severe cases can be a life-threatening condition.

Massage Tuina is a massage technique that is more specific to cope with feeding difficulties in infants with a way to facilitate the circulation of blood in the spleen and digestion, through the modification of acupuncture without needles, this technique uses pressure points on the body's meridians or lines of energy flow so that it is relatively easy to do compared to acupuncture. Massage Tuina has a positive effect on the development of nerves and blood circulation in infants. Massage Tuina that is routinely done by parents can be a stimulation that can have an impact on increasing appetite in toddlers so that their weight will increase.

Health cadres play an important role in educating the community, especially mothers of toddlers, in stimulating the growth and development of toddlers, one of which is Tuina massage. Massage Tuina is a massage technique that is more specific to address the feeding difficulties in infants using the circulation of blood in the spleen and digestion, this technique uses pressure points on the body's meridians or energy flow lines so it is relatively easier to 
do than acupuncture. The purpose of this activity is to increase knowledge and skills, change attitudes and behavior of health cadres regarding toddler health, nutrition, and stimulation of children's growth and development through Tuina massage.

\section{METHOD}

This community service is the application of science and technology, namely the results of research on the effect of massage Tuina on improving children's nutrition. The service was carried out in Pasir Lor village, Karanglewas district. This activity was carried out on March 24, 2021. A population of 45 health cadres from 7 Integrated Service Post (Posyandu) located in Pasir Lor village, Karanglewas Banyumas sub-district, the sample size for this activity amounted to 23 representative cadres from each health cadre. The technique was sampling carried out by purposive sampling, which met the inclusion criteria. Data collection techniques were carried out using a questionnaire to determine the level of knowledge of the respondents and an observation sheet to assess the ability of cadres to perform Tuina massage. Data analysis was carried out using descriptive analysis to describe the level of knowledge and skills of health cadres. The presentation of data is done by presenting data through frequency distribution tables to describe the distribution of knowledge and skills of health cadres. Tools and materials used in this community service activity include projectors, laptops for material presentations, questionnaire sheets and observation sheets to assess knowledge and skills, booklets, and stationery to serve as guides for respondents.

\section{RESULTS}

The level of knowledge of cadres about toddler nutrition and growth and development problems and stimulation of toddler growth before training was mostly in the sufficient category, namely $76.2 \%$ while $23.8 \%$ of cadres already had good knowledge. Meanwhile, the level of knowledge of health cadres about nutrition for toddlers and problems with growth and development of toddlers and stimulation of growth and development after attending training shows that the level of knowledge of cadres is mostly in the Good category, namely $81 \%$. while $19 \%$ are in the sufficient category.

The results of the analysis of the ability of health cadres in doing Tuina massage, most of the health cadres have good skills in doing Tuina massage, which is $62 \%$. While as many as $38 \%$ have sufficient skills in doing Tuina massage. This is because the ability of cadres to absorb training materials well and the age of cadres are relatively young and in their productive age so that concentration and absorption of the material are relatively faster and better.

\section{DISCUSSION}

Based on the results of the activity, it was shown that the cadres' initial knowledge about nutrition for toddlers was adequate, most of them were in the sufficient category, which was $76.2 \%$, this was possible because of the information that had been obtained previously and the experience so far as cadres. Knowledge is the result of human sensing of objects through their senses (eyes, nose, ears, and so on). At the time of the sensing, the process is strongly influenced by the intensity of attention and perception of the object. Most of a person's knowledge is obtained through the sense of hearing (ears), and the sense of sight (eyes) (Notoadmojo, 2007).

The longer a health Cadre is expected to have more experience and knowledge so that more it is hoped that health cadres can serve the community well and more professionally. Cadres who have a longer working period have better relationships with the community because cadres are more well known and have a longer/frequent interaction with the community than new health cadres. The age of the cadre plays a role in determining the working period. Many senior cadres have a mature age too, so they have a strong and respected influence in society (Sistriarani, Nurhayati \& Suratman, 2013). 
The results of the analysis of the knowledge level of health cadres about nutrition for toddlers after the training activities showed that the level of knowledge of cadres was mostly in the Good category, namely $81 \%$. This shows that the outreach activities are effective and able to increase the knowledge of cadres about health about toddler nutrition and the problem of toddler growth and development and stimulation of growth and development. According to Pudjawidjana (2003), knowledge is a reaction from humans to stimulation by the surrounding nature through touch and usually occurs after someone senses a certain object. Knowledge can be interpreted as a collection of information that can be understood and obtained at any time as a tool for adjustment. Knowledge is also an introduction to reality, truth, principles, and rules of an object and is the result of information stimulation for behavior change. (Rizani, Hakimi \& Ismail, 2009)

Knowledge is one of the factors that influence the practice of Posyandu cadres during Posyandu activities. So to change behavior, it is necessary to increase knowledge through regular training so that it raises awareness in cadres to play an active role during Posyandu (Goraahe, 2009). Knowledge is also one of the variables that influence a person's behavior and beliefs, besides that cognitive abilities shape a person's way of thinking and increase understanding of information. The higher one's knowledge about the meaning of health and the benefits of health facilities, the greater one's desire to use health facilities, especially Posyandu (Potter \& Perry, 2009).

The results of the analysis of the ability of health cadres in doing Tuina massage, most of the health cadres have good skills in doing Tuina massage, which is $62 \%$. This is because the ability of cadres to absorb training materials well and the age of cadres are relatively young and in their productive age so that concentration and absorption of the material are relatively faster and better. Knowledge is the result of human sensing of objects through their senses (eyes, nose, ears, and so on). At the time of the sensing, the process is strongly influenced by the intensity of attention and perception of the object. Most of a person's knowledge is obtained through the sense of hearing (ears), and the sense of sight (eyes) (Notoadmojo, 2007

Knowledge and skills of cadres in carrying out their duties can increase and decrease, this can happen if the cadres are less active so they forget about the things that have been studied so that knowledge decreases. The high value of knowledge and skills of cadres is influenced by formal education, cadre courses, frequency of participating in coaching, activeness of cadres in Posyandu, and length of time as cadres. Therefore, it is necessary to refresh, which is intended to maintain and increase the capabilities of these cadres (Syamsianah, A. 2013) Research by Sutiani, R., et al, in 2014 on the description of the knowledge and skills of cadres in monitoring the growth of infants and toddlers in the working area of the Lalang village health center obtained the results of statistical tests with $p$-value $=0.046<0.05$ which means that shows that there is a significant relationship between knowledge with the skills of cadres in monitoring the growth of infants and toddlers (Sutiani.2014).

\section{CONCLUSIONS AND RECOMMENDATIONS}

The level of knowledge of health cadres about toddler nutrition and growth and development problems and stimulation of growth and development after training activities shows that the level of knowledge of cadres is mostly in the Good category, namely $81 \%$ from $23.8 \%$ before training. This is directly proportional to the ability of health cadres in doing Tuina massage, most of the health cadres have good skills in doing Tuina massage, which is $62 \%$. These results indicate that the training activities were effective and able to increase the knowledge and skills of cadres about toddler nutrition and developmental problems for toddlers and growth stimulation and Tuina massage. Knowledge is one of the factors that influence the practice of Posyandu cadres during Posyandu activities. So to change behavior, it is necessary to increase knowledge through regular training so that it raises awareness in cadres to play an active role during Posyandu. 


\section{ACKNOWLEDGMENTS}

Thanks are due to those who have helped in the implementation of community service activities is Thanks are due to the University of Muhammadiyah Gombong which has provided support material and non-material in the implementation of these activities, and the Pasir Lor facilitating our activities so that this activity runs smoothly and we thank the village midwives and cadres who have allowed us to apply our knowledge in the community.

\section{REFERENCES}

Antolis, PV (2012) "Proporsi dan satus gizi anak usia 6-24 bulan yang mengalami kesulitan makan di Semarang", Universitas Diponegoro, Fakultas Kedokteran.

BPS Banyumas. (2020)." Banyumas dalam angka".

Chung KM, Kahng SW. (2006) "Pediatric feeding disorders". Dalam: Fisher JE, O'Donohue WT, penyunting. "Practitioner's guide to evidencebased psychotherapy". New York: Springer;. p. 514.

Fikadu, T., Assegid, S. \& Dube, L. (2014). "Factor associated with stunting among children age 24 to 59 months In Meskan District, Gurage Zone, South Ethiopia: a Case-Control Study. BMC Public Health, 14(800). Diakses dari https://bmcpublichealth.biomedcentral.com/articles/10.1186/1471-2458-14-800

Goraahe, Z.(2009). "Perbedaan pengetahuan tentang peran kader dan kemampuan dalam menilai kurva pertumbuhan balita sebelum dan sesudah pelatihan partisipatif". Semarang; Universitas Dipenogoro.

Nimah, Khoirun dan Siti Rahayu. (2015). "Faktor yang berhubungan dengan kejadian stunting pada balita. media gizi indonesia", Vo. 10 No. 1 Januari-Juni 2015. https://ejournal.unair.ac.id/MGI/issue/view/409

Notoatmodjo, S. (2007). "Promosi kesehatan dan ilmu perilaku". Jakarta: Rineka Cipta, 20.

Pudjawidjana. (2003). "Pengetahuan atlet dan obat doping". PT Askido: Semarang

Potter \& Perry. (2009). "Fundamental keperawatan". Edisi 7. Buku 1. Jakarta : Salemba Medika

Syamsianah, A., \& Winaryati, E. (2013). "Hubungan pengetahuan dan lama kerja dengan ketrampilan kader dalam menilai kurva pertumbuhan balita di posyandu kelurahan tegalsari kecamatan candisari kota semarang". Jurnal Gizi. https://jurnal.unimus.ac.id/index.php/jgizi/article/view/755.

Sistiarani, C. Nurhayati, S \& Suratman. 2013. Peran Kader Dalam Penggunaan Buku Kesehatan Ibu dan Anak. Jurnal Kesehatan Masyarakat. Kesehatan Masyarakat, Fakultas Kedokterandan IImu Kesehatan, Universitas Jenderal Soedirman, Purwokerto, Indonesia. Diakses dari http://journal.unnes.ac.id/nju/index. php/

Sutiani, R. Lubis, Z \& Siagian, A. 2014. Gambaran Pengetahuan dan Keterampilan Kader Posyandu Dalam Pemantauan Pertumbuhan Bayi dan Balita Di Wilayah Kerja Puskesmas Desa Lalang. FKM USU, Departemen Gizi Kesehatan Masyarakat. Di akses di https://jurnal.usu.ac.id/index.php/gkre/article/download/7612/4326

Wirandoko, H,. I.2007. Determinan Status Gizi Anak Usia 2-5 Tahun di Puskesmas Tlogosari Wetan, Kecamatan Pedurungan, Semarang. Tesis. Universitas Diponegoro Yogyakarta Volume 3, No 2(2016). D 